\title{
Teaching Material Development of Educational Research Methodology with ADDIE Models
}

\author{
Deni Adriani ${ }^{1 *}$, Putri Kemala Dewi Lubis ${ }^{2}$, Muhammad Andi Abdillah Triono ${ }^{3}$ \\ ${ }^{1,2}$ Economic Education Study Program, Faculty of Economics, Universitas Negeri Medan \\ ${ }^{3}$ Management Study Program, Faculty of Economics, Universitas Negeri Medan \\ *deni_adriani@unimed.ac.id
}

\begin{abstract}
The purpose of this study is to produce teaching materials based on project based learning in the Research Methodology course. It also aims to determine the effectiveness of teaching methodology courses with a project based learning approach and find out students' responses to teaching materials developed in the form of textbooks and learning videos. The development procedure used in the development of this teaching material is the ADDIE Model Romiszowski. The model consists of five steps, namely: (1) analysis (analize), (2) design, (3) development (development), (4) implementation and (5) evaluation. Based on the results of research and development can be concluded several things as follows: (1) Development of research methodology textbooks based on Project Based Learning using ADDIE models. The analysis phase (Analyze) begins with conducting syllabus analysis, student analysis, concept analysis, task analysis. The design phase are carried out by preparing instruments, choosing the format and initial design of teaching materials, the results of teaching materials are obtained in accordance with the needs of students in the form of textbooks based on Project Based Learning and learning videos. The development phase is done by developing teaching materials into 12 learning activities that are equipped with video learning from each chapter then validated by material experts with a total score of 4.07 while learning media experts with a total score of 4.08 with categories valid and revised according to expert advice.
\end{abstract}

Keywords: Teaching Materials, Development, ADDIE Models

\section{Introduction}

The quality of teaching and learning process is influenced by lecturers, students, teaching methods, teaching materials, the use of learning media, and other factors that support the teaching and learning process. Among these factors teaching material is an important factor in helping the development of students to learn independently in accordance with the abilities and speed of each student.

Teaching material is a set of material that is arranged systematically so that lecturers and students can use it in the lecture process in a comfortable environment and environment for learning. Teaching materials take many forms. The form of teaching materials or learning materials include: (1) Printed materials such as: textbooks, books, worksheets, brochures, hand outs, leaflets, wallcharts; (2) Audio Visual such as: video / film, VCD; (3) Audio like; radio, cassette, audio CD, PH; (4) Visuals: photos, drawings, models / models; (5) Multi Media: interactive $\mathrm{CD}$, computer based, internet [1]. 
Teaching materials are all materials (be it information, tools, and texts) that are arranged systematically that presents a complete figure of the competencies that will be mastered by students and used in the learning process with the aim of planning and studying the implementation of learning [2]. Further explained teaching material is information, tools and texts needed by the teacher / instructor for planning and studying the implementation of learning [3].

The teaching materials referred to are written and unwritten materials. The teaching material group consists of integrated writing, audio visual, electronics and interactive media groups. A teaching material at least includes study instructions (student / lecturer instructions), competencies to be achieved, supporting information, exercises, work instructions that can be in the form of worksheets (LK), and evaluations. Teaching materials or instructional materials generally consist of knowledge, skills and attitudes that students must learn in order to achieve predetermined competencies. In detail, the types of learning materials consist of knowledge (facts, concepts, principles and procedures), skills and attitudes or values [4].

From some of the opinions above it can be concluded that teaching material is a unit consisting of a series of learning activities arranged systematically to help students achieve the goals that have been formulated with effective results, or in short it can be said that teaching materials are curriculum packages provided for students studying independently. Teaching material is arranged systematically so that it has specific objectives, preliminary section, main and closing section, conclusions, according to the level of student ability. The research objective is to produce teaching materials for Research Methodology courses in the form of textbooks that are equipped with learning videos.

\section{Research Methods}

This research is development type of research. Research and development (R\&D) methods are research methods used to research to produce certain products, and then test the effectiveness of these products [5]. This research develops new products in the form of teaching materials for research methodology courses.

This research will be carried out in the Medan State University economic education study program located at Jl.Willem Iskandar Pasar V Medan. The research subjects in this study were students of economic education study programs enrolled in the 2019/2020 school year. The class that the researchers chose was Class B Semester V, amounting to 41 students.

The feasibility analysis of teaching materials is obtained through data validation involving several experts to evaluate the product as a basis for revising the initial product. Data collection tools used in the form of validation sheets provided to experts. Validation sheets are given to experts in the form of a Likert scale.

Table 1. Validation Value Categories

\begin{tabular}{lc}
\hline Answer Category & Statement score \\
\hline Very good & 5 \\
Well & 4 \\
Enough & 3 \\
Not good & 2 \\
Very bad & 1 \\
\hline
\end{tabular}


Then the mean score is searched by using the formula

$R=\frac{\sum_{i=1}^{n} V_{i}}{n} \quad$ (1) [2]

Information:

$\mathrm{R}=$ average of the results of an evaluation by the validator

$\mathrm{Vi}=$ score validator assessment results i-th

$\mathrm{n}=$ many validators

Furthermore the average obtained is adjusted to the following categories:

Table 2. Validity Level Category

\begin{tabular}{ll}
\hline Average & Category \\
\hline $4 \leq$ RTV $\leq 5$ & Very Valid \\
$3 \leq$ RTV $<4$ & Valid \\
$3 \leq$ RTV $<2$ & Invalid \\
$2 \leq$ RTV $<1$ & TidakValid \\
\hline
\end{tabular}

\section{Result and Discussion}

\section{Presentation of Development Results of teaching materials}

The results of this study are (1) a textbook based on Project Based Learning (2) expert assessment of the content or material of textbooks, language assessment and presentation (3) student responses to textbooks that have been made, (4) observations of student enthusiasm class $\mathrm{B}$ semester $\mathrm{V}$ economic education study program in the learning process based on learning activities provided in the textbooks, and (5) the final student test results to see student achievements in the material provided. After doing ADDIE Model which consists of five steps, namely: (1) analysis (analize), (2) design, (3) development, (4) implementation (implementation) and (5) evaluation (evaluation) ). Following is a description of each stage carried out.

\section{1) Analysis Phase}

This stage is carried out to analyze the needs in the lecture process and gather information relating to teaching material products that will be developed include: syllabus analysis, Student analysis, concept analysis and task analysis.

2) The Design Stage

a. Instrument Arrangement

The preparation of the criterion reference test at this stage, researchers compile instruments used to assess the validity of teaching materials to be developed (validation instruments), as well as compile instruments for student responses to products that are developed.

b. Format Selection

The preparation of test instruments and in accordance with the preparation of lecture objectives that serve as a benchmark for the ability of students who refers to Bloom's taxonomy. The next stage is the selection of the textbook format and the initial draft of the 
textbook. The format of the textbooks contained in this study includes a description of learning outcomes, subject matter, material description, material summary, assignments, formative tests and answer keys. The supporting factor in the textbook is the introduction in which there are instructions for the use of textbooks to facilitate students in understanding the contents of the textbooks. This textbook is equipped with a cover, preface, table of contents and also a bibliography at the end of each subject.

c. Initial Design of Teaching Materials

In the design phase of developing semester lecture plans (RPS). From this stage the textbook development design was obtained which consisted of establishing basic competencies, indicators and subject matter according to syllabus and RPS. Preparation of test instruments and in accordance with the preparation of lecture objectives that serve as a benchmark for the ability of students who refer to Bloom's taxonomy. The next stage is the selection of the textbook format and the initial draft of the textbook. The format of the textbooks contained in this study includes a description of learning outcomes, subject matter, material description, material summary, assignments, formative tests and answer keys. The supporting factor in the textbook is the introduction in which there are instructions for the use of textbooks to facilitate students in understanding the contents of the textbooks. This textbook consist of cover, preface, table of contents and also a bibliography at the end of each subject.Based on the selected textbook components then do the writing of the textbook. Writing textbooks begins with attention to the syllabus of courses that have been designed in advance which is the main reference in preparing material in textbooks. Then proceed with developing the textbook material, which $h$ consists of a description of the material, summary, assignments and formative tests. Furthermore, at the final stage the design of the textbook display and layout is then printed and ready for validation by the expert. The design of teaching materials also follows the syntax of project based learning based on leraning models. The theme of the problem was developed in accordance with the results of student observations at the school where the research will be held.

3) Development Stage

Development is the third step in implementing the ADDIE learning system design model. At this stage the design of textbooks in the form of mapping RPS to textbooks will be used as a guide to develop textbooks and develop learning videos.

a. Developing Teaching Materials

Before entering into the material, we must first arrange an introduction the introduction part is the explanation of teaching materials and Project-based learning stages and competencies to be learned. Furthermore, based on the analysis of the material in the RPS on the methodology courses, 12 learning activities were developed that are equipped with video learning.

b. Expert Validation

The validity of the teaching material seen is an assessment in terms of the material, learning media, and learning model experts. Researchers chose two validators to assess the design of textbooks and instructional media. Validation results from experts in the form of suggestions and comments are used to revise textbooks and learning videos that are made. 
The following is the recapitulation of the results of expert validation seen from the aspects of content validity, language validity and validity of the presentation as shown in table 10 below:

Table 3. The results of the material expert validation recapitulation

\begin{tabular}{lcc}
\hline Aspect & $\begin{array}{l}\text { Average } \\
\text { score }\end{array}$ & Category \\
\hline Content validation & 4,05 & Valid \\
$\begin{array}{l}\text { Language } \\
\text { validation }\end{array}$ & 4,00 & Valid \\
$\begin{array}{l}\text { Presentation } \\
\text { validation }\end{array}$ & 4,13 & Valid \\
$\begin{array}{l}\text { Graphic Validation } \\
\text { Average total score }\end{array}$ & 4,10 & Valid \\
& 4,07 & Valid \\
\hline
\end{tabular}

Based on table 3 above, the textbooks of research methodology with a total mean score of 4.07 are valid. This means that the textbook has validity and content, with language that is easy to understand and an interesting presentation and graphic.

Next will be elaborated the results of expert validation related to instructional media (learning videos) note that the average total score for media validity is 4.08 with a valid category, this means that from media validation with four assessment indicators with valid criteria used.

The next step taken by the researcher is the develop phase, namely revision. The validated textbooks were then revised according to the suggestions of the validator. As for what was suggested by the validator including: (1) Formative questions should include all material in the relevant chapter (2) as much as possible to quote from the second source (3) It should be made an example of the formulation of the problem and hypothesis from the existing research case (4) We recommend that the formula be given sequential numbers so easy identification. As for the media validator, it is better to reproduce images that are relevant to the material to encourage students to think critically and improve the layout to make it more interesting. Apart from that there are still a number of other suggestions which are not described in detail, but a revision process has been carried out according to the suggestions of the two validators to improve the draft research methodology textbook.

\section{c. Limited Trial}

Besides being validated by experts, questionnaires were also distributed to students to see responses to the design of textbooks. Input from validators and students are used to revise textbooks that have been made. Limited trials are trial textbooks that have been developed in small classes to get information on the implementation of teaching materials that have been developed and have been validated by experts. The limited trial activity begins with the distribution of teaching materials that have been validated by experts to students.

At the first meeting, the lecturer explained the flow of research carried out and explained the project-based learning to be carried out. This research was conducted on fifth semester students of economic education study program class B as many as 5 students to see the students' responses to the research methodology textbooks which had been compiled based on data obtained information that the total total score was 82.33. The assessment results are included in the practical category. So, the research methodology textbook is good and can be tested to the next stage. 
Then from that will be described student responses to the media (video learning) obtained information that the average total score is 81.33 . The assessment results are included in the practical category. So, the media (learning video) of the research methodology course is good and can be tested to the next stage.

4) Implementation Phase

a. Peer Discussion

Before being used for experiments in class, first discuss with colleagues who are able to study the methodology of research related to teaching materials that have been developed. Through these activities obtained some suggestions for improvement of textbooks and learning videos.

\section{b. Experiments in class}

The implementation phase is a follow-up stage from the development stage. In the implementation phase, researchers duplicate / print textbooks and conduct discussions with colleagues about the shortcomings that exist in the textbooks, and at the same time make improvements, then the last is to implement in class B semester $\mathrm{V}$ economic education study programs. Every learning activity in a textbook contains the stages of a project based learning model.

The researcher will also conduct a post-test to test the ability and find out the learning outcomes of Class B students as many as 41 people after students do the learning by using a project based learning methodology book. Books can be said to be useful if student learning outcomes meet the Minimum Mastery Criteria of 80 and more or equal to achieving the requirements of textbooks said to be effective with $75 \%$ of students completing.

5) Evaluation Phase

The formative evaluations carried out including:

a. Evaluation at the analysis stage is carried out by filling out the evaluation instruments by the content expert. Content expert test is carried out to determine the suitability of the content of teaching materials based on project based learning in research methodology courses.Evaluasi Tahap Desain

b. Evaluation at the design stage is done by filling in the design evaluation instrument by the design expert. The aspects evaluated in the design stage are the selection of learning models, the design of the GSM and the design of the textbook.

c. Evaluation of Development Phase

Evaluation at the development stage is carried out by filling out development evaluation instruments by media experts. The aspect which is evaluated in the development stage is the accuracy in mapping the RPS to the textbooks and learning videos that are in accordance with the textbook content.

d. Evaluation of implementation Phase

Evaluation at the implementation stage is done by filling in the expert test questionnaire and student response questionnaire. Evaluation at the implementation stage is the final evaluation in the research methodology textbook. 


\section{Discussion}

The development model used in ADDIE Model are (1) analyze, (2) design, (3) development, (4) implementation and (5) evaluation. Visually, the ADDIE Model stage results in an initial draft of the Project Based Learning methodology-based teaching textbook called the educational research methodology textbook and 12 learning videos. Furthermore, the draft textbook and the learning video are validated by 2 experts.

Expert validation was carried out on two aspects, namely the validation of the contents of the material and the learning media. The total score of assessment of content validity is 4.05 with a valid category. Whereas for language validation, the number of assessment scores is 4.0 with a valid category, the number of validation assessment scores for the presentation of textbooks is 4.13 with a valid category, validation of the graphic aspects of the number of assessment scores 4.10 with a valid category. The draft textbook as a whole is declared valid for use with an average total score of 4.07. This means that the assessment of the content of the material, language, presentation, and graphic textbooks are in the valid category for use with revisions in accordance with the validator's suggestion.

Then validate the learning media in this case a learning video created using the camtasia studio application. From the results of the validation carried out by two experts obtained a mean total score of 4.08 with a valid category. This shows that the learning videos compiled as many as 12 videos are suitable for use in the next stage.

Here are some suggestions from the validator (1) We recommend that formative questions should include all the material in the relevant chapter (2) as much as possible to quote from the second source (3) We recommend that you make examples of problem formulations and hypotheses from existing research cases (4) We recommend that formulas are given serial numbers to make identification easy. As for the media validator, it is better to reproduce images that are relevant to the material to encourage students to think critically and improve the layout to make it more interesting. Apart from that, there are still a number of other suggestions that are not detailed, but a revision process has been carried out in accordance with the recommendations of the two validators for the improvement of the draft research methodology textbooks and learning videos.

In the next stage, draft textbooks and learning videos were given to five students called limited trials. The draft textbook is assessed based on the criteria contained in the assessment questionnaire and student responses totaling 4 assessment criteria. From the results of the assessment of five students obtained an average number of assessment scores of $82.33 \%$ with a practical category, while the responses of students to the learning video obtained an average total score of $81.33 \%$ with a practical category to use. From the comments and suggestions from students, the researchers did not make many revisions because most students gave comments that tended to be positive towards textbooks and learning videos. The product revision is carried out if the trial is still found errors or deficiencies [4]. Referring to the results of the student questionnaire, this textbook does not need to be revised anymore and can be used for testing to the next stage.

The next stage of the draft textbook is tested on the real class. The test was conducted on students in class B semester V of the economic education study program TA.2019 / 2020 with a total of 41 students. Trials conducted four times, learning activities using Project Based Learning textbooks, in which with this textbooks students are invited to learn by exercises, especially in writing research proposals as interesting as possible so that they are easy to remember. So that students are demanded to be more enthusiastic and enthusiastic in lectures. In this trial the researcher made observations on learning activities. 


\section{Conclusion}

Based on the results of research and development it can be concluded several things as follows: (1) Development of research methodology textbooks based on Project Based Learning using the ADDIE model. The analysis phase (Analyze) starts with conducting syllabus analysis, student analysis, concept analysis, task analysis. The design phase are done by preparing instruments, choosing the format and initial design of teaching materials, the results of teaching materials are obtained according to the needs of students in the form of textbooks based on Project Based Learning and learning videos. The development phase (Development) is done by developing teaching materials into 12 learning activities that are equipped with video learning from each chapter then validated by material experts with a total score of 4.07 while learning media experts with a total score of 4.08 with categories valid and revised according to expert advice.

Furthermore, the results of the trial are limited to some students in class B semester V of the Medan State University economic education study program. The students' responses to the textbook with an average total score of 82.33 with a practical category. As for the media in the form of instructional videos with an average total score of 81.33 with easy to use categories. Implementation phase (Implementation), carried out by conducting experimental activities that are still in the process of completing the experimental stages. The last is the Evaluation Phase (Evaluation) by evaluating several stages of development as previously discussed.

\section{References}

[1] I. M. T. d. I. M. Kirna. Pengembangan Bahan Ajar Metode Penelitian Pendidikan Dengan Addie Model. Journal IKA. (2017).

[2] G. S. S. D. G. H. D. Ni Komang Yesiati. Pengembangan Modul Ajar Berbasis Project Based Learning Pada Mata Plajaran Menggabungkan Audio Kelas XI Multimedia. KARMAPATI. (2017).

[3] A. Prastowo. Pengembangan Bahan Ajar Tematik. Jakarta: Kencana. (2014).

[4] Prasetyo. Desain Pembelajaran Berbasis Pendidikan Karakter. Yogyakarta: Ar-Ruzz Media. (2012).

[5] D. Yulianti. Pengembangan Modul Berbasis Project Based Learning. Radiasi. (2014).

[6] S. R. Asmara. Pengembangan Bahan Ajar Ipa Berbasis Model PJBL Di Kelas VI SD. Journal Education and development Institut Pendidikan Tapanuli Selatan. (2018).

[7] Sugiyono. Metodologi Penelitian Penddikan Pendekatan Kuantitatif, Kualitatif, dan $R \& D$. Bandung: Alfabeta. (2011).

[8] E. P. Widoyoko. Teknik Penyusunan Instrumen Penelitian. Yogyakarta: Pustaka Pelajar. (2012).

[9] D. H. J. Kurniati. Kemampuan Berpikir Tingkat Tinggi. Jurnal Penelitian dan Evaluasi. (2016).

[10] Octariani \& Halimah. Pengembangan Bahan Ajar Berbasis Project Based Learning Berbantuan Software Geogebra. Journal of Mathematics Education and Science. (2018). 
[11] E. Kosasih. Strategi Belajar dan Pembelajaran Iplementasi Kurikulum 2013. Bandung: Yrama Widya. (2014).

[12] Oktarinah et.al. Pengembangan Bahan Ajar Berbasis Model Pembelajaran Proyek Materi Alat-Alat Optik untuk Kelas X SMA. Jurnal Inovasi dan Pembelajaran Fisika. (2016).

[13] T. d. Kurniawati. Pengembangan Draf Bahan Ajar pada Mata Kuliah Basic Reading Program Studi Bahasa Inggris. Jurnal Pendidikan Bahasa. (2015).

[14] D. Muri. Pengembangan Bahan Ajar Ilmu Pengetahuan Alam Project Based Learning Di Sekolah Dasar Negeri Pontianak. Jurnal Pendidikan dan Pembelajaran. (2018).

[15] A. Daryanto. Pengembangan Perangkat Pembelajaran (Silabus, RPP, PHB, Bahan Ajar). Gava Media. (2014). 